\title{
QUANTUM MECHANICAL INVESTIGATIONS OF SELF-ASSEMBLED SYSTEM CONSISTING OF PEPTIDE NUCLEIC ACID, SENSITIZER, AND LIPID PRECURSOR MOLECULES
}

\author{
J. Tamulienè and A. Tamulis \\ Institute of Theoretical Physics and Astronomy of Vilnius University, A. Goštauto 12, LT-01108 Vilnius, Lithuania \\ E-mail: gicevic@itpa.lt
}

Received 15 June 2005

\begin{abstract}
Quantum mechanical investigations were performed to find a suitable sensitizer to peptide nucleic acid monomer with thymine and cytosine basis. It was found that the 1,4-dihydroquinoxaline and 7,8-dimethylisoalloxazine molecules could be used as a sensitizer. The low quantum yield efficiency could be due to the formation of different geometrical structures of the same compound with different optical properties. The process of the self-reproducing lipid vesicle can be accompanied by fluorescence.
\end{abstract}

Keywords: sensitizer, photodissociation

PACS: 82.39.Jn

\section{Introduction}

In recent years the interest has grown in the study of life-like behaviour in artificial systems. The motivation of researchers was the hope to distill principles that are necessarily leading to complex phenomena like Life without being forced to copy nature to a large extent or in great detail. Various models of selfreplications were suggested. Replication in Laing's model is achieved by self-inspection, where the description of the object to be replicated (the genome) is dynamically constructed concomitantly with its interpretation [1]. In other self-replication models the genome is essentially predetermined either by direct design or by artificial evolution. There are studies of self-replication that can be achieved in two ways: a string can extend itself horizontally along one level and then cut itself into two pieces that are either already replicas of their parent or will beget such replicas, or it can use a copy operation to create a double strand that will separate into two daughters that are either already copies of their parent or will grow into such copies $[2,3]$. Simpler computational models of self-directed replication called sheathed loops have been developed and it was shown that self-replication is not an inherently complex phenomenon but rather an emergent property arising from local interactions in systems that can be much simpler than is generally be- lieved [4]. However, until recently it has been difficult to separate the ideas about how to bridge nonliving and living matter from the theories of origins of life. The first approach to bring nonliving and living matter is based on both RNA properties: (i) to have catalytic and information storage capabilities, (ii) to act simultaneously as DNA and protein do in contemporary life [5]. However, a self-replicating RNA molecule is a very difficult and serious problem and this does not allow to suggest this molecule as "first living molecule" [6]. Although, recently it is proposed to use an RNA-based chemistry (very similar to the information chemistries) in contemporary natural cells [7]. At present there exist several origins of life picture. One of them is stating that proteins probably are the first biomolecules and as an example there should be mentioned Suzuki's work [8], in which he has created an evolutionary core memory system named SeMar which is revised so that the entire action of the core might proceed by parallel execution of proteins. An alternative origins of life picture was originally developed by Luisi et al., and Deamer and Morovitz, who worked towards assembling proto cells based on a self-reproducing lipid vesicle encapsulating a self-replicating RNA protogene $[9,10]$. Rassmunsen et al. designed a protoorganism inspired by the original concepts for a protocell by Luisi and coworkers, but this model was different from others because they did not start with a self- 


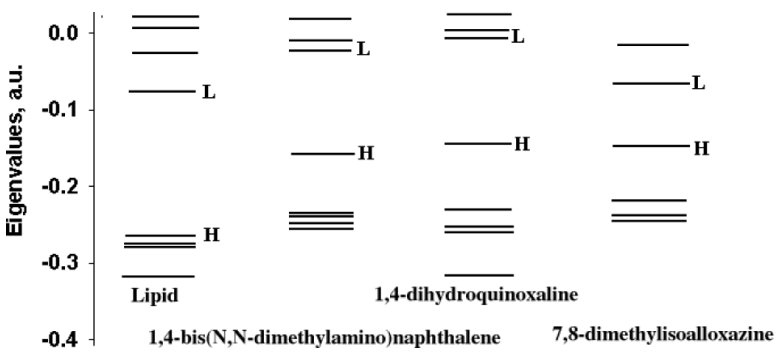

Fig. 1. Relative positions of the eigenvalues of lipid and sensitizers: 1,4-bis(N,N-dimethylamino)naphthalene, 1,4-dihydroquinoxaline, and 7,8-dimethylisoalloxazine.

replicating container or a self-replicating gene that was combined afterwards, and, the most important, instead of RNA they applied peptide nucleic acids (PNA) [11]. In the above-mentioned proto-organism, the synthesis of a 1,4-bis(N,N-dimethylamino)naphthalene sensitizer attached to PNA monomer takes place to increase quantum efficiency because in this case the sensitizer coupled with an electron relay system can be introduced to block back the electron transfer process, and thus increase the quantum yield of surfactant production. Thus, the question arises which sensitizer is better to joint with PNA oligomer with cytosine-thymine bases (no adenine/sensitizer/guanine complex is available yet), so that quantum efficiency should be as high as possible, and how to simplify the appropriate sensitizer search.

We assume that the selection of the sensitizers could be performed basing on the relative position of the eigenvalues of the isolated sensitizer and lipid molecules (Fig. 1) as their interaction strongly influences the quantum efficiency of proto-metabolic process proposed by Rassmunsen et al. [11]. It is implied that the HOMO of a sensitizer molecule must be higher than that of lipid, and the same holds for the LUMO placement of this molecule. It should be emphasized that the cases where the mixing of the eigenvalues due to their interaction can be avoided are more successful. Without going into details, we may state that these simple investigations allow us to obtain the sensitizer which could increase quantum efficiency in comparison with that when 1,4-bis $(\mathrm{N}, \mathrm{N}$ dimethylamino)naphthalene is joined with a PNA fragment with thymine-cytosine (TC) bases.

\section{Computational methodology}

The quantum chemical ab initio Hartree-Fock (HF) and density functional theory (DFT) investigations were applied with the Berny geometry optimization to gain structural information on investigated compounds [12-18]. The geometrical and electronic structures of a single photodonor molecules substituted by a specific group to provide an attachment of the molecule to a PNA fragment with the TC bases to propose as a suitable sensitizer and a lipid molecule were investigated applying B3LYP exchange-correlation functional with 6-311G** basis set $[19,20]$ (Fig. 2). As it was mentioned above, there was assumed that the selection of sensitizer could be based on the investigation of the relative positions of eigenvalues (see Fig. 1). So, after selection of the suitable sensitizer, this molecule was joined to PNA fragment with a cytosine base. There is no doubt that more correct results should be obtained when the TC base sequence is investigated. However, investigations of such kind require large computer time as well as memory resources. On the other hand, to exhibit that the applied methodology and model are correct, the same investigations of 1,4bis(N,N-dimethylamino)naphthalene, well-known as a good sensitizer in an experimentally obtained replicating process, are performed and compared with the investigation results obtained with a selected sensitizer. Briefly, both investigation results coincide and applied model described the experimentally proposed mechanism of replication well enough. It implies that the used methodology and the model are rather correct for the above investigations.

To obtain the geometrical structure of the sensitizer (S) attached to the PNA C-base fragment, the HF method with 6-31G basis set was applied. It is emphasized that initially the lipid molecule was placed in a way that followed from the $a b$ initio investigations of a PNA fragment with the TC bases and $\mathrm{S}$ attached near to the $C$ monomer [21-23]. Then the spectra, the nature of molecular orbitals, and the transitions are evaluated applying the time dependent B3LYP/6-31G method [24-26]. Notice that in this paper we presented only the successful cases of our investigated sensitizers refusing the others which are worse from quantum mechanical point of view in comparison with 1,4-bis $(\mathrm{N}, \mathrm{N}-$ dimethylamino)naphthalene.

\section{Investigation results}

Let us present the investigation results of 1,4dihydroquinoxaline and 1,4-bis(N,N-dimethylamino) naphthalene molecules. The view of relative eigenvalue positions of lipid, 1,4-bis(N,N-dimethylamino) naphthalene, and 1,4-dihydroquinoxaline suggested as 

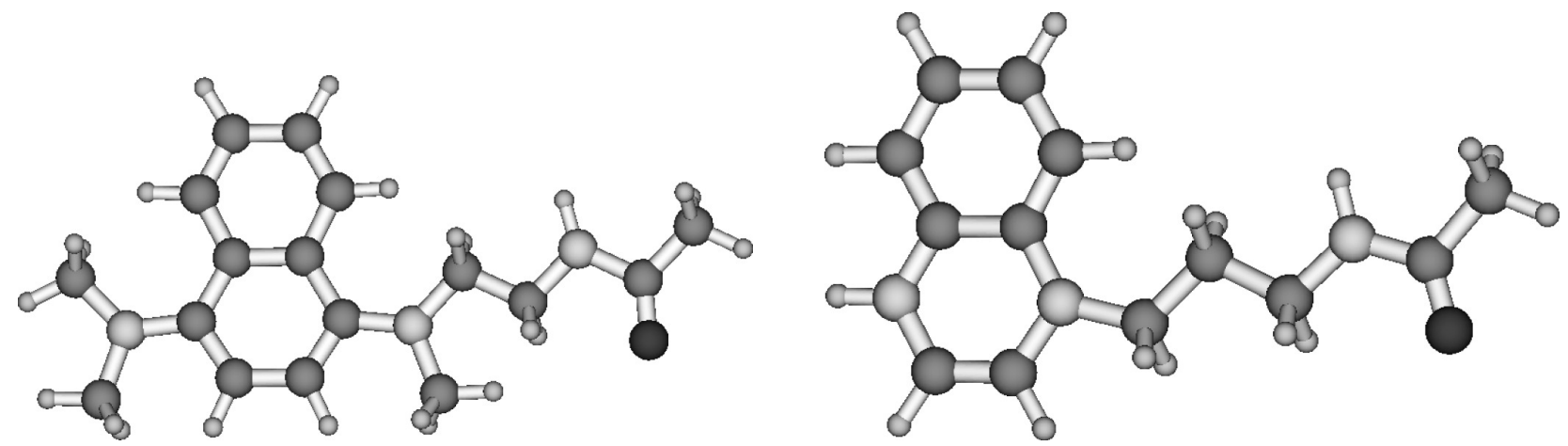

Fig. 2. Views of the 1,4 bis(N,N-dimethylamino)naphthalene and 1,4-dihydroquinoxaline that are suitable as sensitizers to PNR fragment with $\mathrm{T}$ and $\mathrm{C}$.

sensitizer molecules for the self-assembled structures is presented in Fig. 1.

It is seen that HOMO and LUMO of both molecules are higher than those of lipid, respectively. It is most important that the resonant interaction of the lipid and sensitizer orbitals is absent. In addition, the comparison of the placement of the PNA fragment with TC sequence eigenvalues and that of sensitizer also indicated non-interacting orbitals. It is emphasized that HOMO of the above fragment is lower and LUMO is higher than those of the described molecules, respectively. It allows us to foresee that when sensitizers are joined to PNA fragment with TC bases the HOMO of this derivative will consist of molecular orbital of the sensitizer. Summarizing all the above-mentioned results, it is possible to foresee that in the PNA fragment with cytosine and sensitizer - the lipid derivative, the orbital nature remains unchanged, i.e. the orbitals do not mix and split, therefore it is possible to simplify the structure of the PNA fragment with TC bases. Thus, the T was removed. Based on the investigation results, to avoid too large computational time and memory resources, our latest investigations have been performed adapting the compound in which the sensitizer is implemented in the PNA fragment with C. The lipid molecule is also present in this compound. Firstly, the geometries have been obtained via the HF/6-31G approach. Excitation energies were calculated using the time-dependent (TD) DFT implementation in Gaussian [17]. In this case the B3PW91 functional within 6-31G basis set is used. Of course, the most consistent calculations from a methodological point of view are performed when geometries and excitation energies have been obtained using the same basis set and functional. However, before using the above described methodology the geometry search investigations of compound consisting of 1,4-bis(N,N-dimethylamino)naphthalene attached to the PNA C-base fragment and lipid have been per-

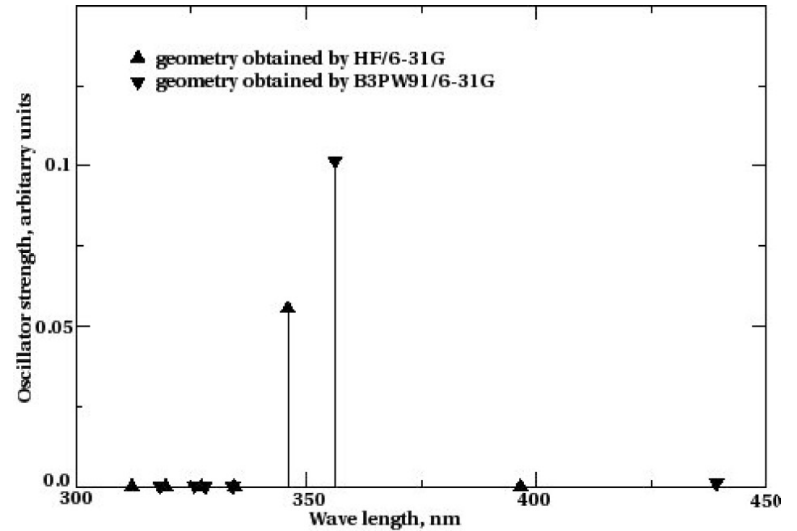

Fig. 3. Spectrum of the PNA fragment with $\mathrm{C}$ base and 1,4bis(N,N-dimethylamino)naphthalene attached to the $\mathrm{C}$ monomer and lipid when the geometry of this compound is obtained using both HF/6-31G and B3PW91/6-31G methods with Berny geometry optimization.

formed both by HF/6-31G and B3PW91/6-31G, while the excitation energies are investigated only applying the B3PW91/6-31G approach. It is emphasized that both spectra of the compound obtained with different approaches coincide well enough (Fig. 3). The largest shift between the first transitions is $42.7 \mathrm{~nm}$, that is much more smaller than the excitation energy shift arisen due to solvent influence. On the other hand, the point here is that the suggested 1,4-dihydroquinoxaline molecule should be useful as a sensitizer in the process of replication. Thus the used methodology (structure of compound obtained by HF/6-31G, and excitation energy by TD B3PW91/6-31G) is consistent enough.

In the absorption spectra of the above described system with 1,4-dihydroquinoxaline, the vertical excited state corresponds to $\pi \rightarrow \pi^{*}$ transition from the above PNA fragment to lipid. It is the transition from HOMO to LUMO, while the second one (from HOMO to LUMO+1) corresponds to $\pi \rightarrow \pi^{*}$ transition from a different part of the PNA fragment (Fig. 4). This 


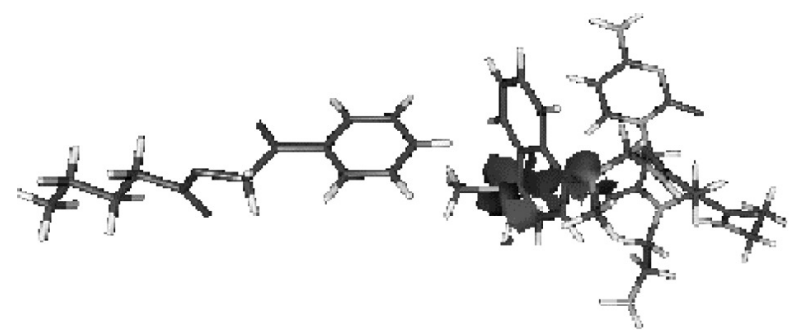

Hомо

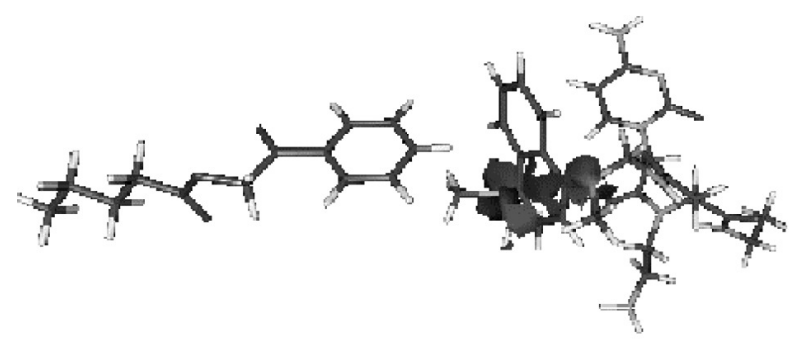

HOMO

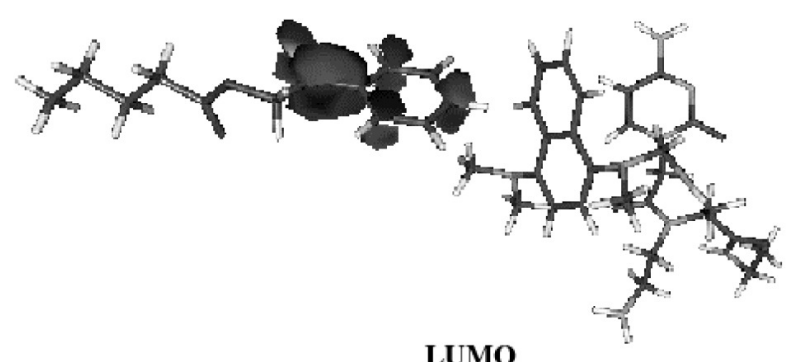

LUMO

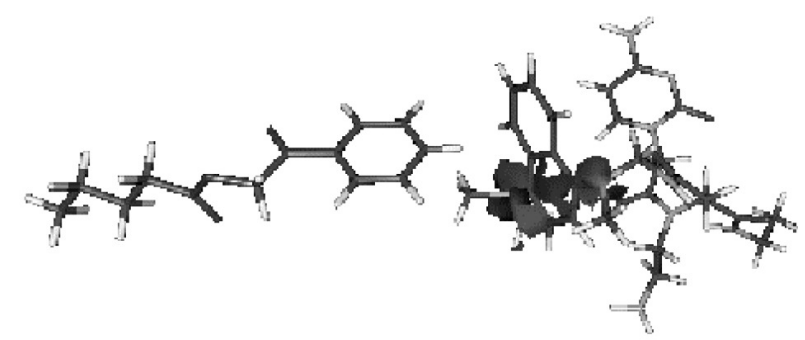

LUMO+1

Fig. 4. Several molecular orbitals that are important in the self-assembly process. The first vertical excited state corresponds to $\pi \rightarrow \pi^{*}$ transition HOMO to LUMO. The transition is forbidden because the HOMO orbitals are perpendicular to the LUMO one. Only the second transition from HOMO to LUMO+1 is allowed.

implies that during photoexcitation the charge redistribution in the PNA fragment takes place and then the charge is slowly transferred to lipid, and later it should be transferred to sensitizer due to rotation and vibrations. This result allows us to foresee the absence of the fast electron transfer and high quantum efficiency as a consequence.

The geometry search of a compound consisting of the 1,4-dihydroquinoxaline as a sensitizer attached to the PNA C-base and lipid has been performed by HF/6$31 \mathrm{G}$ approach. It is emphasized that two different placements of lipid in respect to PNA fragment are obtained. The views of these structures are presented in Fig. 5 (called $I$ ) and Fig. 6 (called $I I$ ). It is difficult to say which one of the above-mentioned placements is more preferable because their energy difference is equal to $0.27 \mathrm{eV}$, that is too small to make conclusions. Probably both these geometrical structures occur. However, the structure $I I$ is more successful for self-assembly because the transition is allowed in the visible wavelength region (see Fig. 7).

In this successful case the LUMO of the compound consists of an orbital of a lipid molecule (Fig. 8) (also in the case $I I)$. It is possible to see that only the excitation from HOMO to LUMO+4 orbital is allowed (Figs. 7 and 8), while other transitions from HOMO to LUMO and LUMO+n (where $n=1-3$ ) are forbidden because the above virtual orbitals are perpendicular to HOMO. It implies that in this case the
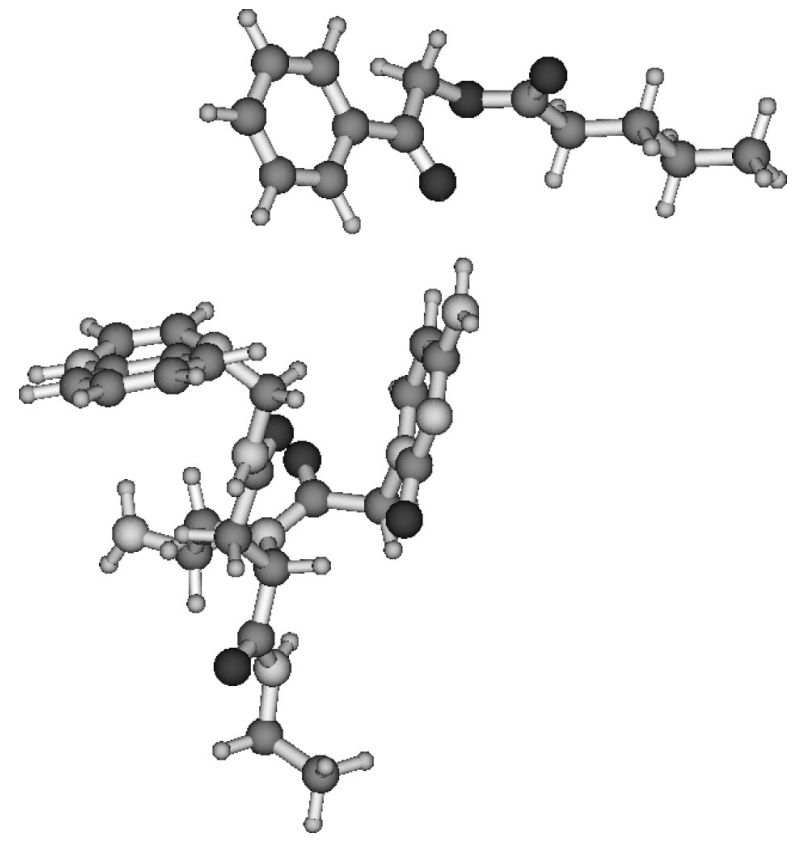

Fig. 5. Images of PNA fragment with $\mathrm{C}$ and 1,4-dihydroquinoxaline. The structure is called $I$.

photoexcitation leads to a charge transfer to lipid due to vibration and rotation and the relaxation should be more slow than that in the case when the PNA fragment with cytosine, as well as with cytosine-thymine, is joined with 1,4-dihydroquinoxaline as sensitizer. It is emphasized that during vibration and rotation the charge on lipid should occur two times: during 


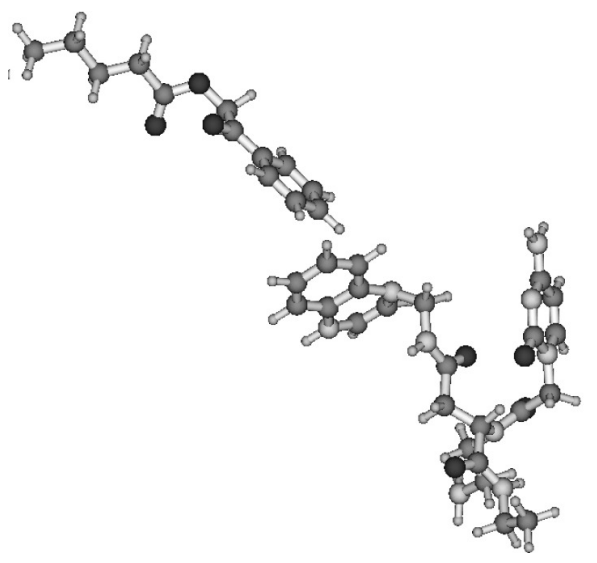

Fig. 6. Images of PNA fragment with $\mathrm{C}$ and 1,4-dihydroquinoxaline. The structure is called $I I$.

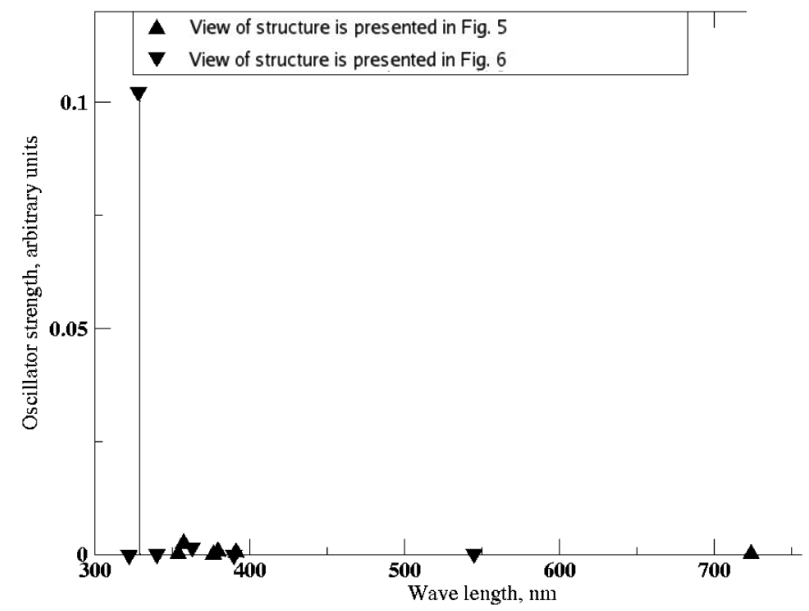

Fig. 7. Spectra of the lipid and PNA fragment with $\mathrm{C}$ and the newly suggested sensitizer (1,4-dihydroquinoxaline).

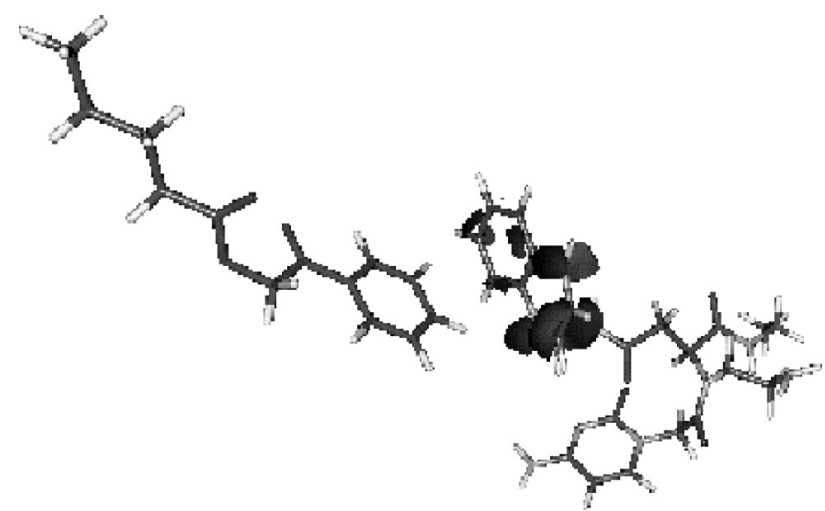

HOMO transfer to LUMO+3 and LUMO orbitals. The results prove that the quantum yield efficiency could be higher than that in the case of insertion of 1,4-bis(N,Ndimethylamino)naphthalene as sensitizer to PNA fragment with $\mathrm{C}$ and $\mathrm{T}$. However, let us remember that two different structures of lipid and the PNA fragment with $\mathrm{C}$ and 1,4-dihydroquinoxaline as sensitizer have been obtained (Fig. 5, 6). The excitation energies of these two forms are different (Fig. 4).

The said above implies that the quantum yield efficiency decreases when the excitation by a certain wave length is present, because only a part of the above PNA fragment compounds is involved in the self-replication reaction. Thus, the reason of low quantum yield efficiency could be not only due to the fast back electron transfer, but also due to the possibility to obtain different geometrical structures of the same compound. It implies that these derivatives should be excited by several wave lengths, then the quantum yield should be as high as possible, but without doubt the newly suggested 1,4-dihydroquinoxaline molecule should be applied as a suitable sensitizer in order to qualify PNA as a true proto-gene.

The possibility to use the 7,8-dimethylisoalloxazine molecule as a sensitizer in order to qualify PNA as a true proto-gene was also investigated. The view of the molecule and its placement in respect to PNA sequence is presented in Figs. 9 and 10. It is possible to see that LUMOs of both lipid and 7,8-dimethylisoalloxazine molecules are very close, the difference is $0.18 \mathrm{eV}$ (see Fig. 1). The placement of the eigenvalues of the above molecule in respect to that of lipid is not conventional because there exists the interaction between these
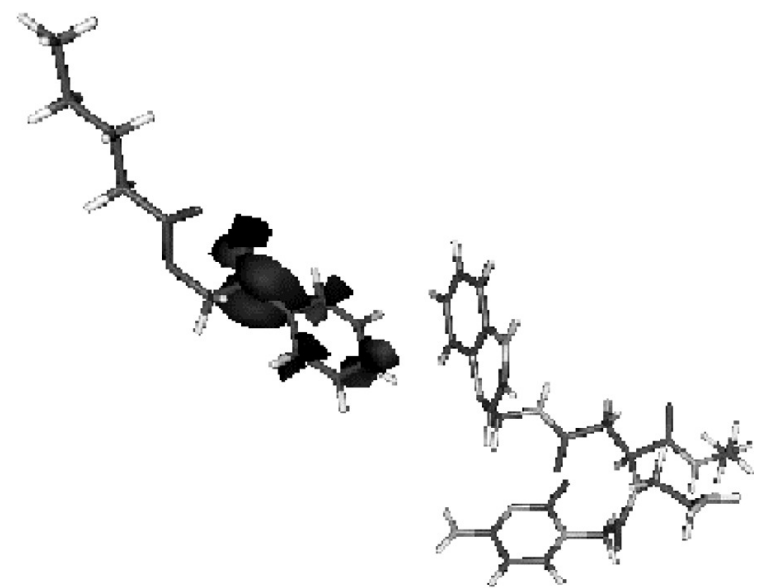

LUMO

Fig. 8. Molecular orbitals that are important in the excitation process. The first excited state corresponds to $\pi \rightarrow \pi^{*}$ transitions HOMOLUMO. The transition is forbidden because the HOMO orbitals are perpendicular to the LUMO+n (where $n=0-3$ ) one (see spectra in Fig. 7). 


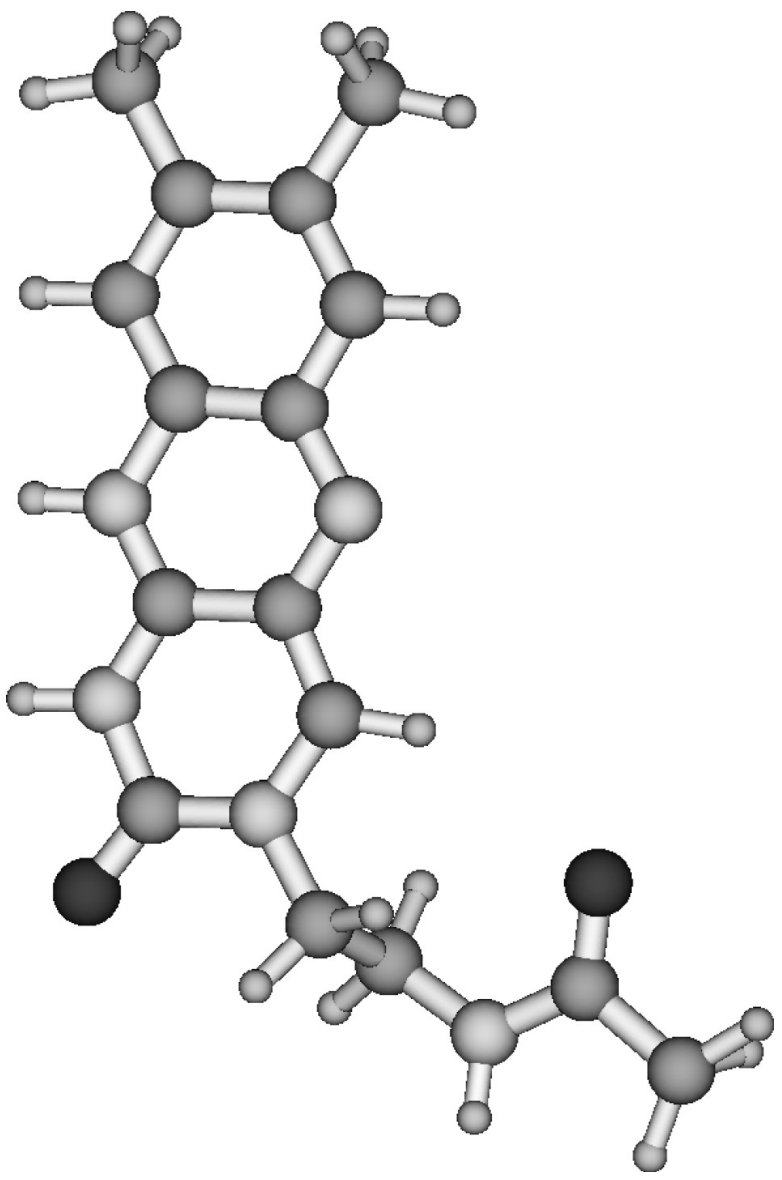

Fig. 9. View of the 7,8-dimethylisoalloxazine that is suitable as a sensitizer to the PNR fragment with $\mathrm{T}$ and $\mathrm{C}$.

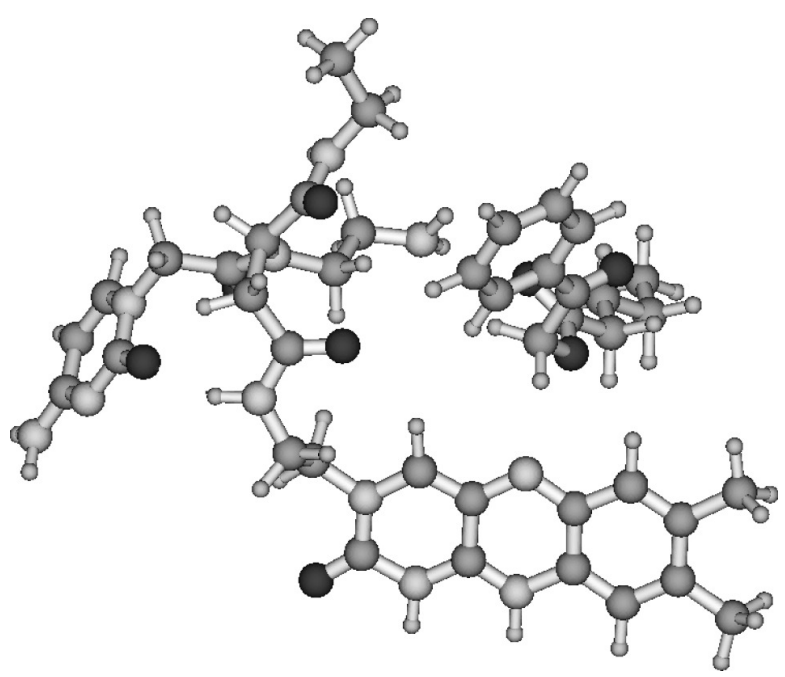

Fig. 10. Images of PNA fragment with $\mathrm{C}$ and 7,8-dimethylisoalloxazine.

orbitals. Due to this interaction the orbitals split into the derivative of lipid and PNA fragment with $\mathrm{C}$ and $\mathrm{S}$, and the LUMO of that consists mostly of orbitals of the sensitizer (Fig. 11). Thus, in the first excited state that corresponds to HOMO-LUMO transition, the charge is only redistributed in the sensitizer and the excitation energy is mostly absorbed. Still more important, the second excited state, which corresponds to transition from the sensitizer to lipid, lasts sufficiently long and energy is emitted slowly (Fig. 12). In this case the emission is more probable than the relaxation through rotation and vibration, if compared to that of 1,4-dihydroquinoxaline and 1,4-bis $(\mathrm{N}, \mathrm{N}-$ dimethylamino)naphthalene. So, during the second excitation, the charge is transferred from PNA fragment with $\mathrm{C}$ and $\mathrm{S}$ to lipid and the energy dissipates slowly, therefore the back electron transfer process is blocked. The results prove that 7,8-dimethylisoalloxazine could be attached to PNA monomer to increase the quantum efficiency of surfactant production. Moreover, the process of the self-reproducing lipid vesicle could be followed by fluorescence.

\section{Conclusions}

Based on the investigation results, it is evident that the account of the relative positions of single molecule eigenvalues should help in the selection of the sensitizer. Without any doubt the 1,4-dihydroquinoxaline and 7,8-dimethylisoalloxazine molecules should be used as sensitizers.

On the other hand, the reason of low quantum yield efficiency could be not only due to the fast back electron transfer, but also due to the possibility of formation of different geometrical structures of the same compound. As an example, two different structures of PNA fragment with $\mathrm{C}$ and 1,4-bis(N,Ndimethylamino)naphthalene are obtained. However, only one geometrical structure of this compound is optically excited in the way that is important for selfreplication.

It is obtained that in the case when 7,8-dimethylisoalloxazine is applied as a sensitizer the process of the self-reproducing lipid vesicle could be followed by fluorescence.

\section{Acknowledgements}

The work was funded via PACE (Programmable Artificial Cell Evolution), European Integrated Project in the EU FP6-IST-FET "Complex Systems Initiative", and partially by the Lithuanian State Science and Studies Foundation. 


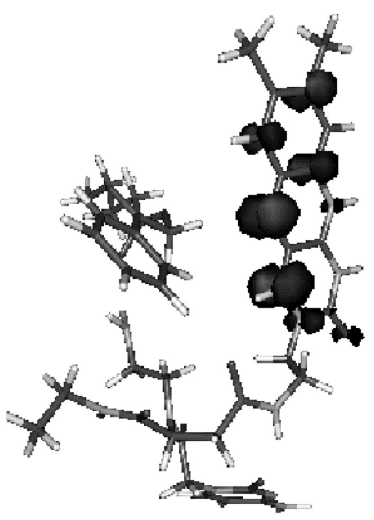

HOMO

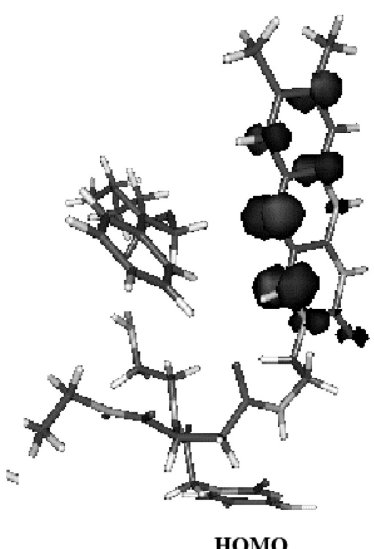

HOMO
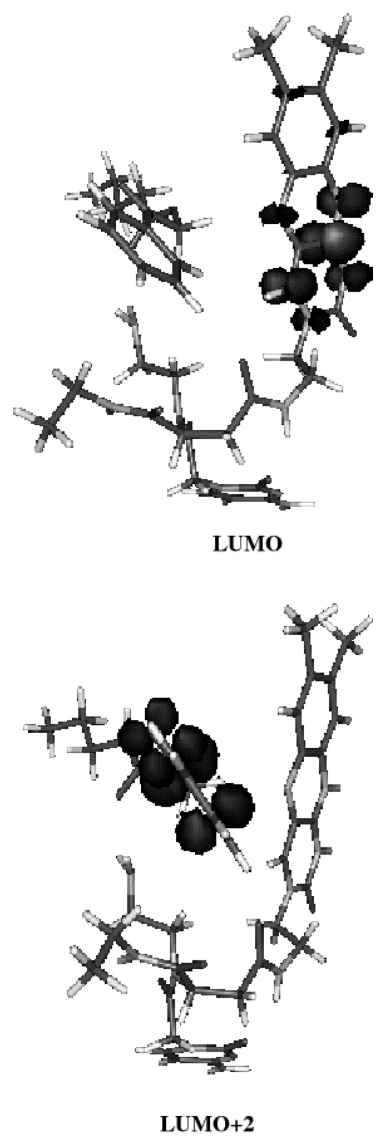

Fig. 11. Molecular orbitals that are important in the excitation process. The first excited state corresponds to $\pi \rightarrow \pi^{*}$ transitions of HOMO-LUMO. The transition is allowed. The second excitation corresponds to $\pi \rightarrow \pi^{*}$ transition from HOMO to LUMO+2. The transition is a long lasting one (see spectrum in Fig. 12).

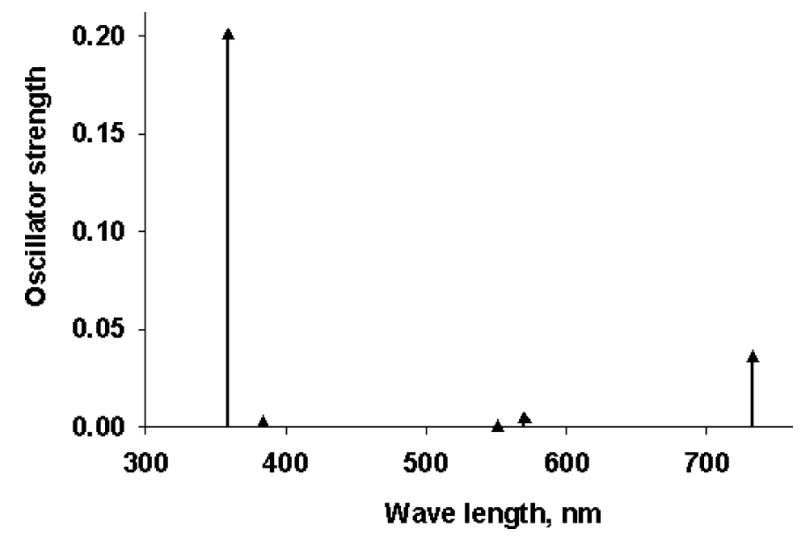

Fig. 12. Spectrum of the lipid and PNA fragment with $\mathrm{C}$ and 7,8dimethylisoalloxazine.

We are grateful to Prof. A. Graja and Poznan Supercomputing and Networking Centre for the possibility to use supercomputer CRAY and Gaussian98 package.

We thank Prof. M.L. Balevičius for true discussion.

\section{References}

[1] M. Sipper, Artificial Life 4, 237 (1998).

[2] H.C. Morris, Typogenetic: A logic for artificial life, in: Artificial Life, ed. C.G. Langton (Addison-Wesley, Renwood City, CA, 1989) pp. 369-395.

[3] L. Varetto, J. Theor. Biology 160, 185 (1993).

[4] J.A. Reggia, S.L. Armentrout, Hui-Hsien Chou, and Yun Peng, Science 259, 5099 (1993).

[5] R. Gestland, T. Cech, and J. Atkins, The RNA World (Cold Spring Harbor, 1999).

[6] W. Jonston, W.P. Unrau, M. Lawrence, M. Glasner, and D. Bartel, Science 292, 1319 (2001).

[7] J. Szostak, D. Bartell, and P.L. Luisi, Nature 409, 387 (2001).

[8] H. Suzuki, Artificial Life 6, 103 (2000).

[9] L. Luisi, M. Giomini, M. Pileni, and B. Robinson, Biochim. Biophys. Acta 947, 209 (1988).

[10] H. Morowitz, D. Deamer, and B. Heinz, Orig. Life Evol. Biosph. 18, 281 (1988).

[11] S. Rassmunsen, L. Chen, M. Nilsson, and S. Abe, Artificial Life 9, 267 (2003).

[12] R. McWeeny and G. Dierksen, J. Chem. Phys.49, 4852 (1968).

[13] A.D. Becke, J. Chem. Phys. 98, 5648 (1993).

[14] B. Miehlich, A. Savin, H. Stoll, and H. Preuss, Chem. Phys. Lett. 157, 200 (1989).

[15] C. Lee, W. Yang, and R.G. Parr, Phys. Rev. B 37, 785 (1988).

[16] J.P. Perdew, K. Burke, and Y. Wang, Phys. Rev. B 54, 16533 (1996).

[17] J.P. Perdew, J.A. Chevary, S.H. Vosko, K.A. Jackson, M.R. Pederson, D.J. Singh, and C. Fiolhais, Phys. Rev. B 48, 4978 (1993).

[18] K. Burke, J.P. Perdew, and Y. Wang, in: Electronic Density Functional Theory: Recent Progress and New Directions, eds. J.F. Dobson, G. Vignale, and M.P. Das (Plenum, 1998).

[19] R. Krishnan, J.S. Binkley, R. Seeger, and J.A. Pople, J. Chem. Phys. 72, 650 (1980).

[20] T. Clark, J. Chandrasekhar, G.W. Spitznagel, and P.V.R. Schleyer, J. Comp. Chem. 4, 294 (1983).

[21] V.A. Rassolov, M.A. Ratner, J.A. Pople, P.C. Redfern, and L.A. Curtiss, J. Comp. Chem. 22, 976 (2001).

[22] A.D. McLean and G.S. Chandler, J. Chem. Phys. 72, 5639 (1980).

[23] V.A. Rassolov, J.A. Pople, M.A.Ratner, and T.L. Windus, J. Chem. Phys. 109, 1223 (1998).

[24] R. Bauernschmitt and R. Ahlrichs, Chem. Phys. Lett. 256, 454 (1996).

[25] R.E. Stratmann, G.E. Scuseria, and M.J. Frisch, J. Chem. Phys. 109, 8218 (1998).

[26] M.E. Casida, C. Jamorski, K.C. Casida, and D.R. Salahub, J. Chem. Phys. 108, 4439 (1998). 


\title{
KVANTINIS MECHANINIS SAVISUSIDARANČIŲ SISTEMŲ, TURINČIU SAVYJE PEPTIDINIU NUKLEININIŲ RŪGŠČIŲ, SENSITIZERIŲ IR LIPIDŲ PREKURSORIŲ MOLEKULES, TYRIMAS
}

\author{
J. Tamulienè, A. Tamulis
}

Vilniaus universiteto Teorinès fizikos ir astronomijos institutas, Vilnius, Lietuva

\section{Santrauka}

Atlikus 1.4-di(N,N-dimetilamino)naftaleno, 1,4-dihidrochinoksalino ir 7,8-dimetilizoaloksazino molekulių kvantinès chemijos teorinius tyrimus, teigiama, kad jos gali būti panaudotos kaip sensitizeriai. Tie sensitizeriai ijungiami i peptidinès nukleininès rūgšties (PNR) grandinèlę tam, kad vyktų lipidų prekursorių molekulių fo- todisociacija, kuri būtina biomolekulinių robotu savaiminiam dauginimuisi. Remiantis tyrimų rezultatais parodyta, kad lipido prekursoriaus molekulès fotodisociacijos reakcijos kvantinè išeiga gali būti nedidelè dèl vienodos energijos, bet skirtingos geometrinès sandaros junginiu susidarymo. Kita vertus, vykstant aukščiau minètai fotodisociacijos reakcijai gali būti pastebima fluorescencija. 